$18^{\text {th }}$ Conference of the Egyptian Society of Animal Production, Hurghada, Egypt, November 7 - 10, 2018

\title{
EFFECT OF ZINC SOURCE ON NUTRIENT DIGESTIBILITY, RUMEN FERMENTATION AND RUMENMICROBIAL POPULATION COUNT IN SHEEP
}

\author{
M.M. Farghaly, S.M. Mousa and M.A. Abd El-Rahman \\ Animal Production Department, Faculty of Agriculture, Assiut University, Egypt
}

This study investigated the impacts of dietary zinc source, organic or inorganic on nutrient digestibility, rumen fermentation and rumen microbial population count in sheep. Three digestibility trials were carried out using nine local rams randomly assigned into three groups, 3 rams each, each trial lasted or three weeks. The control group was fed the basal diet consisting of wheat straw and concentrates mixture, while the other two tested groups were fed the same basal diet supplemented with $20 \mathrm{mg} \mathrm{Zn/head/day} \mathrm{as} \mathrm{Zinc} \mathrm{Sulphate}\left(\mathrm{ZnSO}_{4}\right)$ or $20 \mathrm{mg} \mathrm{Zn/head/day} \mathrm{as}$ Zinc methionine (Zn-Meth). Animals were fed $60 \%$ of their requirements as concentrate mixture while, wheat straw was given as roughages ad libitum. The basal diet contains $40 \mathrm{mg} \mathrm{Zn} / \mathrm{kg} \mathrm{DM}$. The results referred that, $\mathrm{Zn}$-methionine improved $(\mathrm{P}<0.05)$ the digestibility of crude fiber. Also, supplement $\mathrm{ZnSO}_{4}$ or $\mathrm{Zn}-$ Meth to rams diet increased ( $\left.>0.05\right) \mathrm{CP}$ digestibility as compared with control group. Average ruminal $\mathrm{pH}$ values for $\mathrm{ZnSo}_{4}$ and $\mathrm{Zn}$-Meth groups were higher $(\mathrm{P}<0.05)$ than control group. However, the total VFA and $\mathrm{NH}_{3}-\mathrm{N}$ concentration in rumen fluids were not significantly affected by treatments. Supplement $\mathrm{Zn}$ in form of inorganic and organic sourceto sheep rations increased $(\mathrm{P}<0.05)$ total protozoa counts. However, the total bacterial counts were not affected by $\mathrm{Zn}$ supplementation. The higher value of nitrogen retained was recorded in $\mathrm{Zn}-\mathrm{Meth}$ group followed by control group. In conclusion: Zinc supplementation, particularly Zn-Meth increased protozoa population that may reflect on nutrient digestibility and nitrogen retained.

Keywords: Zn-methionine, Zn sulphate, digestibility, rumen fermentation, rumen microbial population count 